\title{
Verification by Tests of Models Proposed for Synchronous Machines, Excitation Control Systems, Water Supply and Turbines and its Control Systems for Colbún and Machicura Power Plants.
}

\author{
J. L. Agüero IEEE Senior Member (*), L. Bastidas Almarza. (**), M. C. Beroqui (*) and S. Fuentes Bomvin. (***)
}

\begin{abstract}
In this paper several models proposed for Excitation Control Systems, Synchronous Machines, Prime Movers Control System and Turbines corresponding to the Hydraulic power plants of Colbún and Machicura are shown and verified.

These power plants are located in the "Interconnected Central System" (SIC), Chile's largest grid and are part of the Colbún subsystem. This grid subsystem also bears industrial load. It supplies energy to "El Teniente" -world's largest copper mineand to several paper manufacturing plants.

The models were used to study the Colbún subsystem under island operation when the SIC blacks out due to under-frequency conditions.
\end{abstract}

Index Terms-- Control systems - Excitation systems Governors - Hydraulic turbines - Limiters - Modeling - Power System Stabilizer - Synchronous Machines -Testing.

\section{INTRODUCTION}

$\mathrm{S}$ EVERAL tests were conducted at Colbún and Machicura hydraulic power plants in order to verify the dynamic models proposed for their constituent control loops.

The tests were previously simulated on the models, which were built based on the information given by the owners of the plants. The models were then checked or modified to reproduce tests records.

Colbún power plant is equipped with two 250 MVA, 13.8 $\mathrm{kV}$ electric generators. Its prime movers are $168 \mathrm{~m}$ nominal net head, $310 \mathrm{~m}^{3} / \mathrm{s}$ maximum flow, $245 \mathrm{MW}$ maximum power Francis turbines. Machicura power plant is equipped with two $50 \mathrm{MVA}, 13.8 \mathrm{kV}$ electric generators. Its prime movers are 37 $\mathrm{m}$ nominal net head, $310 \mathrm{~m}^{3} / \mathrm{s}$ maximum flow, $45 \mathrm{MW}$ maximum power Kaplan turbines.

The excitation is static for both power plants, and it is controlled by a Siemens Simatic C1 Excitation Control System. The controlled rectifier bridge is fed through a 13.8 $\mathrm{kV} / 0.816 \mathrm{~V}, 1850 \mathrm{KVA}$ transformer connected to the generator terminals. Colbún power plant has a Siemens Power

This work was partially supported by COLBÚN SA.

(*) J. L. Agüero and M. C. Beroqui work in IITREE-LAT. Facultad de Ingeniería, Universidad Nacional de La Plata. (1900) 48 y 116. La Plata. Argentina. e-mail: iitree@iitree-unlp.org.ar.

(**) L. Bastidas A. works in Colbún SA. Avda. Apoquindo 4775, piso 12, Las Condes. Santiago. Chile. e-mail: LBastidas @)colbun.cl.

(***) S. Fuentes B. works in Universidad Técnica Federico Santa María. Avda España 1680. Valparaiso. Chile. e-mail: sergio.fuentes@)eli.utfsm.cl.
System Stabilizer (PSS).

The turbine Control System of both power plants is a Siemens Teleperm C.

The models were used in studies aimed at defining the setting for island operation of Colbún subsystem. These models were used as well to define the setting for interconnected operation with the SIC. These settings were introduced in the corresponding control system and verified by test.

\section{Excitation Control System Model}

\section{A. General description}

Fig. 1 shows a simplified block diagram of the Excitation Control System Model. The output is the Field Voltage (EFD). The inputs are:

- Controlled Voltage set point (U SP)

- Measured Terminal Voltage (UT)

- Measured Terminal Active Current (ITA)

- Measured Terminal Reactive Current (ITR)

- Measured Active Power (P)

- Measured Field Current (IFD)

The Excitation Control System is constituted by the following main blocks: Power System Stabilizer, IFD Thermal Limiter, Reactive Power Limiter, IFD Maximum Limiter, Compensation, Automatic Voltage Regulator (AVR) and Rectifier. Inputs and output are expressed in per unit.

\section{B. Automatic Voltage Regulator (AVR). Control P+I}

AVR calculates an error signal by adding together U SP, UT, PSS, Comp, IFD Th and Q lim. (see Fig. 1).

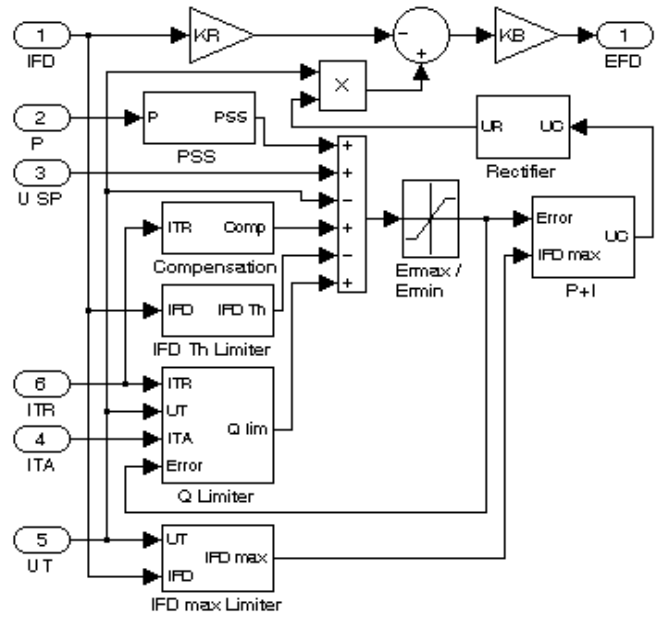

Fig. 1. Excitation Control System Model. Simplified block diagram 